\title{
ENDOMETRIOSIS WITH LYMPHATIC SPREAD
}

\section{P. Narmadha ${ }^{1}$, P. Viswanathan², Rehana Tippoo ${ }^{3}$, U. Manohar ${ }^{4}$, Lavanya Kumari ${ }^{5}$}

\section{HOW TO CITE THIS ARTICLE:}

P. Narmadha, P. Viswanathan, Rehana Tippoo, U. Manohar, Lavanya Kumari. "Endometriosis with Lymphatic Spread". Journal of Evolution of Medical and Dental Sciences 2014; Vol. 3, Issue 54, October 20;

Page: $12499-12503$, DOI: $10.14260 /$ jemds/2014/3654

ABSTRACT: Pelvic endometriosis is a common gynaecologic problem. But the histogenesis of endometriosis was not so clear. Various theories have been proposed by Pathologist in the past. Here we present a case of endometriosis of fallopian tube by lymphatic spread which has been proved histopathologically.

KEYWORDS: Endometriosis, lymphatic spread.

INTRODUCTION: Endometriosis is defined as presence of endometrial glands or stroma or both in ectopic location which tend to respond to ovarian hormones in a manner similar to that of mucosa which lines endometrial cavity of uterus. This case is about endometriosis presenting in the fallopian tube with a specific finding.

CLINICAL HISTORY: The patient presented with irregular menstruation for 3 months. History of lower abdominal pain associated with back pain was present.

On Examination: No palpable lesions was found.

Ultrasonography: Bilateral multiseptated ovarian cyst with septal thickness of $5 \mathrm{~mm}$ seen.

Operative Procedure: Right sided ovariectomy with left sided partial ovariectomy was done. Intraoperatively a frozen pelvis was seen. Uterus was densely adherent to sigmoid colon anterior to bladder. Only part of fundus was seen. Right tubo ovarian mass adherent to bowel and omentum was seen. Right side tube and ovary with chocolate cyst removed. Left side deroofing of chocolate cyst was done.

MACROSCOPIC FINDINGS: Specimen of ovary and fallopian tube adherent to one another was received in the department of pathology. On cut section ovarian tissue was identified along with lumen of fallopian tube. There were some cystic spaces largest measuring $1.5 \mathrm{X} 1 \mathrm{~cm}$. Filled with haemorrhagic material. Sections were taken and studied.

MICROSCOPIC FINDINGS: Sections studied revealed endometrial glands and stroma studded amidst tubal musculature. The glands were lined by endometrial type of lining epithelium. One focus showed endometrial gland inside a lymphatic channel lined by flattened endothelial cells. There was a paratubal cyst lined by flattened epithelium and a Walthard cell rest with cystic degeneration was also identified. 


\section{CASE REPORT}

DISCUSSION: The criteria for diagnosis of endometriosis is presence of two components-endometrial glands and its stroma. It occurs during reproductive years (Fox 1983). The sites of involvement are usually the ovaries, uterine ligaments, peritoneum of bladder, ${ }^{1}$ rectosigmoid junction, uterus and tubes, umbilicus, laparotomy scars, hernia sacs, appendix, vagina and vulva. It undergoes cystic changes associated with menstruation.

\section{Numerous hypothesis have been Postulated:}

1. First believed to be originated is from either Wolffian ${ }^{3}$ or mullerian rests. ${ }^{4}$

2. Retrograde menstruation. ${ }^{4}$

3. Lymphatic pathway for dissemination ${ }^{5,6}$

4. Hematogenous spread.7,8

5. Direct implantation of endometrial tissue. ${ }^{9}$

6. Coelomic metaplastic theory- Endometrial metaplasia and ability of surface epithelium of ovary to give rise to glands and stroma.

Response to oestrogen and progesterone stimulation produces cystic endometriosis. Repeated haemorrhages produces inflammatory reaction leading to scar formation and adhesions.

Endometriosis commonly involves the peritoneum of fallopian tubes where involvement of fallopian tube produces patchy areas, nodules or cyst that may be pigmented or non-pigmented associated with adhesion formation.

It can involve any area of full thickness of the tubal wall. When lumen is involved it produces infertility. If muscularis layer is involved it produces concentric layers of smooth muscle proliferation. Endometriotic foci may undergo a decidual reaction, hyper secretory glandular changes and arias stella reaction as a response to intrauterine and ectopic pregnancy. Endometriosis also can develop after tubal ligation, usually in the area of proximal stump. ${ }^{11}$

\section{GROSS FEATURES:}

1. Tiny or large cystic masses.

2. Dome shaped, dark bluish colouration with tan to brownish staining of adjacent tissues.

3. Fibrous adhesion and scarring.

4. Well encapsulated.

5. $20 \mathrm{~cm}$ in diameter.

6. Lumen- dark brown fluid watery to syrupy in colour.

7. Wall is usually shaggy with dark brown deposits.

MICROSCOPIC FEATURES: The characteristics features are presence of endometrial glands and stroma along with the following secondary features:

1. Lining of large cysts converted in to granulation tissue with numerous histiocytes and fibrosis.

2. Degradation products of blood and ceroid will be present.

3. Rarely granulomatous nodules will be present.

4. Free hemosiderin and pigment laden macrophages will be seen. 


\section{CASE REPORT}

\section{MICROSCOPIC PICTURES:}

\section{SHOWS ENDOMETRIAL GLAND AND STROMA SURROUNDED BY MUSCULAR TISSUE}

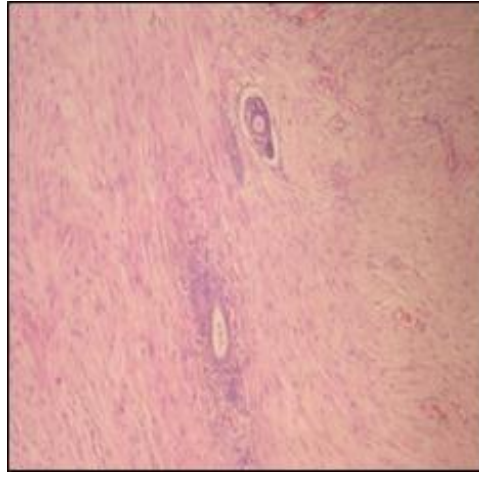

FIG. 1: $10 \times 3$

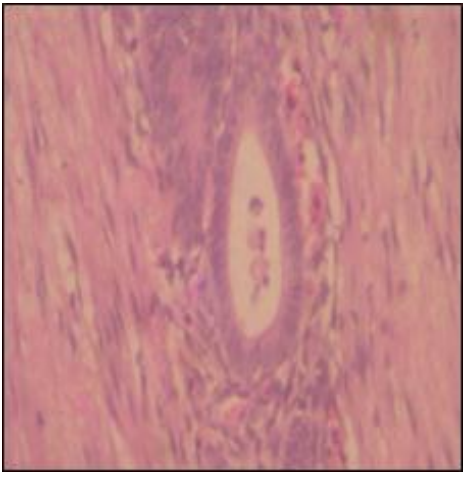

FIG. 2: $20 X 3$

SHOWS A ENDOMETRIAL GLAND PRESENT WITHIN A LYMPHATIC C HANNEL LINED BY FLATTENED ENDOTHELIAL CELLS.

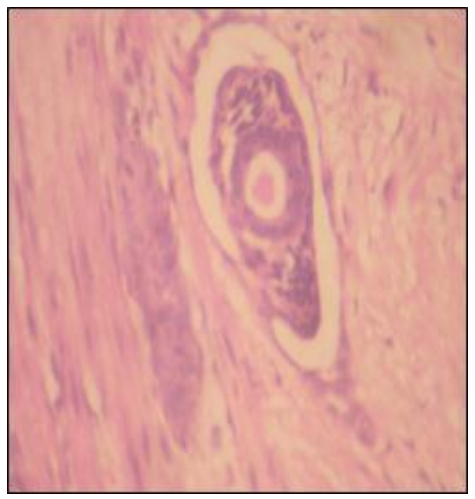

FIG. 3: 20X

SHOWS PARATUBAL CYST LINED BY BENIGN FLATTENED EPITHELIUM. ADJACENT TO IT IS SEEN ENDOMETRIAL GLAND AND STROMA WITHIN THE WALL OF THE TUBE.

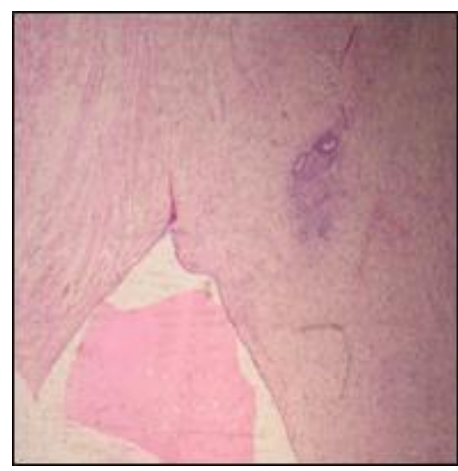

FIG. 4: 10X

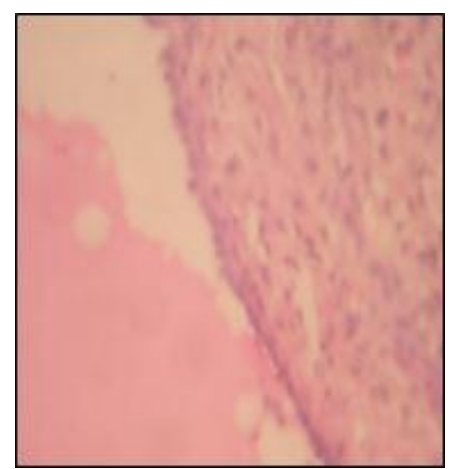

FIG. 5: $20 \mathrm{X}$

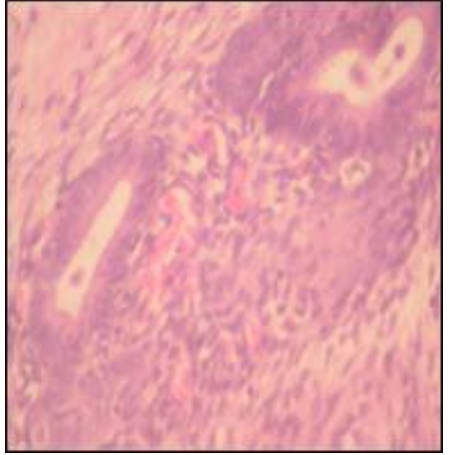

FIG. 6: 40X 
SHOWS WALTHARD CELL REST CYST ADJACENT TO TUBAL MUSCULATURE

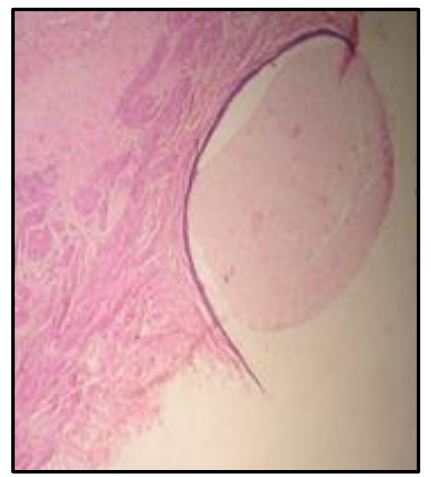

FIG. 7: 4X

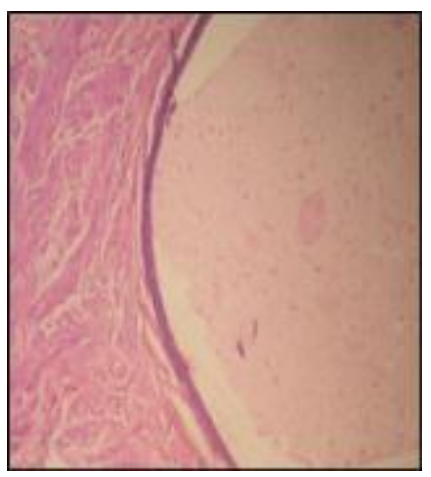

FIG. 8: 10X

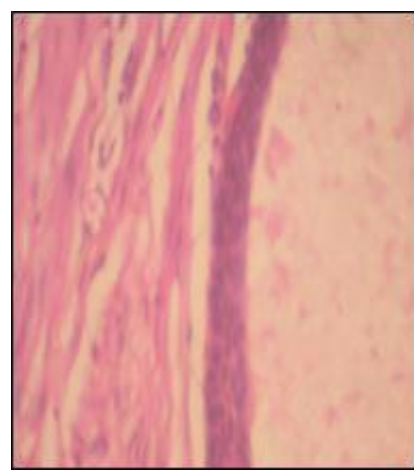

FIG. 9: 40X

\section{SHOWS ENDOMETRIAL TISSUE WITHIN MUSCULATURE OF THE TUBE.}

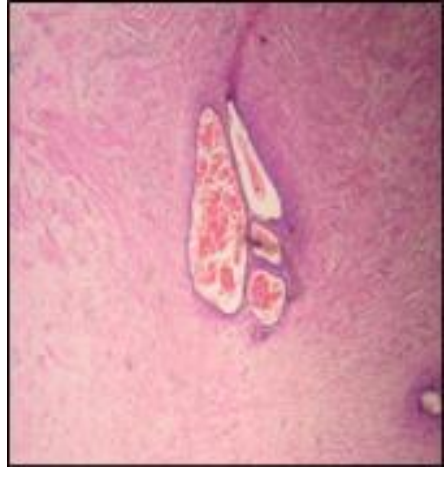

FIG. 10: $4 \mathrm{X}$

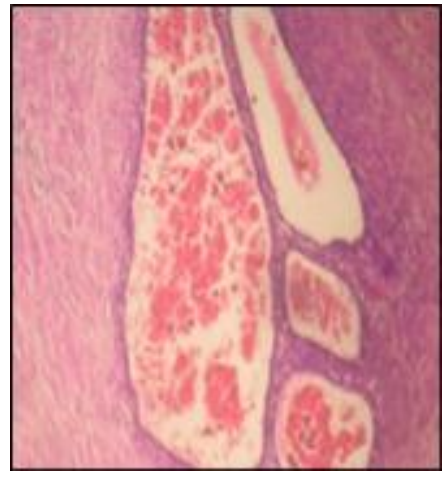

FIG. 11: 10X

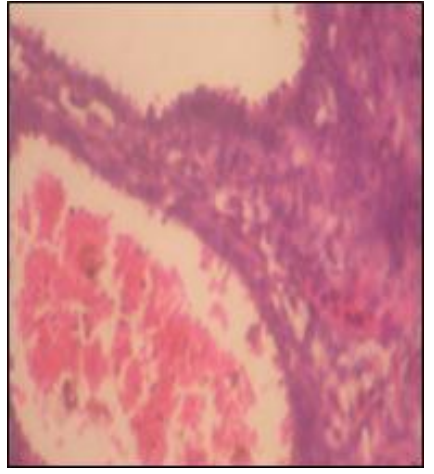

FIG. 12: 40X

CONCLUSION: In the present case, multiple sections studied revealed endometrial tissue emboli within the lymphatic channel. This shows that theory of dissemination by lymphatic spread has been proved and documented.

\section{REFERENCES:}

1. Clement PB: Diseases of peritoneum (including endometriosis).In Kumaran RJ (ed): Blausteins Pathology of the Female Genital Tract, 5th ed. Alan Liss. New York. 1987.

2. Cullen T S. Discussion: symposium on misplaced endometrial tissue. American Journal of Obstretics and Gynaecology.1925; 10:732-733.

3. Sampson J A perforating hemorrhagic (chocolate) cysts of ovary, their importance and especially their relation to pelvic adenomas of the endometrial type. Archives of surgery 1921; 3: 245- 323.

4. Halban Y. Hysteroadenosis metastatica. Archive fur Gynakologie.1925; 124: 457-482.

5. Javert C T. Observations on the pathology and spread of endometriosis based on theory of benign metastases. American Journal of Obstretics and Gynaecology 1951; 62: 477-487. 
6. Tidman M J, MacDonald D M. cutaneous endometriosis: a histopathological study. Journal of the American Academy of Dermatology.1988; 18: 373-377.

7. Steck W D, Helwig E B CUTANEOUS ENDOMETRIOSIS. Journal of the American medical association 1965; 191:167-170.

8. Novak E, Delima. A correlative study of adenomyosis and pelvic endometriosis, with special reference to the hormonal reaction of ectopic endometrium. american journal of obstrectics and gynaecolgy 1948; 56: 634-644.

9. Young RH, Scully RE: Metastatic tumors of ovary: a problem oriented approach and review of the recent literature. Semin Diagn Pathol 1991; 8: 250-276.

\section{AUTHORS:}

1. P. Narmadha

2. P. Viswanathan

3. Rehana Tippoo

4. U. Manohar

5. Lavanya Kumari.

\section{PARTICULARS OF CONTRIBUTORS:}

1. $3^{\text {rd }}$ Year Post Graduate, Department of Pathology, Rajah Muthiah Medical College, Annamalai University.

2. Professor, Department of Pathology, Rajah Muthiah Medical College, Annamalai University.

3. Professor, Department of Pathology, Rajah Muthiah Medical College, Annamalai University.

4. Professor, Department of Pathology, Rajah Muthiah Medical College, Annamalai University.
5. Professor, Department of Obstetrics and Gynaecology, Rajah Muthiah Medical College, Annamalai University.

\section{NAME ADDRESS EMAIL ID OF THE CORRESPONDING AUTHOR:}

Dr. P. Viswanathan,

Professor,

Department of Pathology,

Faculty of Medicine,

Rajah Muthiah Medical College,

Annamalai University,

Chidambaram-608002,

Tamilnadu, India.

Email: drpviswanathan2013@gmail.com

Date of Submission: 29/09/2014.

Date of Peer Review: 30/09/2014.

Date of Acceptance: 14/10/2014.

Date of Publishing: 18/10/2014. 